\title{
TINJAUAN ETIKA BISNIS ISLAM DALAM STRATEGI PEMASARAN HOME INDUSTRI TAHU SARI RASA
}

\author{
Syaeful Bakhri, Leliya dan Latip Purnama \\ Fakultas Syari'ah dan Ekonomi Islam \\ Institut Agama Islam Negeri Syekh Nurjati Cirebon \\ e-mail: sultan01aulia@yahoo.com,leliya12@yahoo.co.id \\ dan latippurnama.lp@gmail.com
}

\begin{abstract}
Every organization has a marketing strategy that must be executed in carrying out its business activities. Strategy is the organizational means used to achieve its goals. Society in general is expecting business people to prioritize the needs of society by not ignoring the ethics in business. Therefore, business and society should maintain good relations through the application of ethical values in business such as honesty, modesty, and high sense of responsibility. Problems in this study are (1) How the implementation of marketing strategies in increasing sales at the company Tahu Sari Rasa? (2) How is the marketing strategy at Tahu Sari Rasa company in terms of Islamic business ethics?. The method used is qualitative research. Data collection techniques that will be used is by doing Observation, Interview and Documentation. From the results of the study, the authors observed the marketing strategy by using the marketing mix and review of Islamic business ethics on the company Tahu Sari Rasa. The result is that the marketing strategy needs to improve the promotion aspect because it is still traditional and the Islamic business ethics review is appropriate.
\end{abstract}

Keywords: Strategy Marketing, and Islamic Business Ethics.

\begin{abstract}
Abstrak
Setiap organisasi perusahaan memiliki strategi pemasaran yang harus dijalankan dalam melaksanakan kegiatan bisnisnya. Strategi merupakan sarana organisasi yang digunakan untuk mencapai tujuannya. Masyarakat pada umumnya sangat mengharapkan para pelaku bisnis mengutamakan kebutuhan masyarakat dengan tidak mengabaikan etika dalam berbisnis. Oleh karena itu, pelaku bisnis dan masyarakat hendaknya menjaga hubungan baik melalui penerapan nilai-nilai etika dalam berbisnis seperti kejujuran, kesopanan, dan rasa tanggung jawab yang tinggi. Masalah dalam penelitian ini adalah (1) Bagaimana penerapan strategi pemasaran dalam meningkatkan penjualan pada perusahaan Tahu Sari Rasa? (2) Bagaimana strategi pemasaran pada perusahaan Tahu Sari Rasa ditinjau dari etika bisnis Islam? Metode yang digunakan adalah penelitian kualitatif. Teknik pengumpulan data yang akan digunakan yaitu dengan melakukan Observasi, Wawancara dan Dokumentasi. Dari hasil penelitian, penulis mengamati strategi pemasaran dengan menggunakan bauran pemasaran dan tinjauan etika bisnis Islam pada perusahaan Tahu Sari Rasa. Hasilnya strategi pemasaran perlu memperbaiki segi promosi karena masih tradisional dan tinjauan etika bisnis Islam sudah sesuai.
\end{abstract}

Kata Kunci: Strategi Pemasaran, dan Etika Bisnis Islam. 


\section{PENDAHULUAN}

Fungsi pemasaran tidak bisa dilepaskan dari fungsi bisnis itu sendiri. Sebab pemasaran merupakan aktivitas perencanaan, pelaksanaan, dan pengawasan atas programprogram yang dirancang untuk menghasilkan transaksi melalui target-target yang sudah menjadi program sebuah perusahaan. Hal ini bertujuan untuk menguasai semua segmen yang ada dalam sebuah pasar guna memenuhi kebutuhan perorangan atau kelompok berdasarkan asas saling menguntungkan melalui pemanfaatan produk, harga, promosi, dan distribusi. Oleh sebab itu, apapun yang dilakukan oleh aktivitas pemasaran adalah berorientasi kepada kepuasan pasar. Kepuasan pasar dalam pengertian di sini adalah kondisi saling ridha serta rahmat antara pembeli dan penjual atas transaksi yang dilakukan dalam aktivitas jual beli dalam sebuah pasar. Dengan adanya keridhaan ini, maka akan menjadi aktivitas dalam sebuah pasar yang akan tetap berjalan dan berlangsung normal, serta memberikan pengaruh yang besar terhadap kelangsungan produk-produk perusahaan dalam jangka waktu yang panjang. ${ }^{1}$

Setiap organisasi memiliki strategi pemasaran yang harus dijalankan dalam melaksanakan kegiatan bisnisnya. Strategi merupakan sarana organisasi yang digunakan untuk mencapai tujuannya. Salah satu bentuk dari strategi bisnis adalah strategi pemasaran yang berkaitan dengan bagaimana cara meyakinkan pembeli terhadap produk yang akan dijual. Untuk dapat meyakinkan pembeli maka penjual harus memiliki keyakinan bahwa produk yang dijual memang patut dibeli. Karena itu perlu dipertimbangkan beberapa aspek dalam menentukan strategi pemasaran yang akan dijalankan dengan memperhatikan marketing mix yaitu strategi produk (product), harga (price), distribusi (place)

\footnotetext{
${ }^{1}$ Muhammad dan Alimin, Etika dan Perlindungan Konsume (Yogyakarta: BPFE, 2004), 73-74.
}

dan promosi (promotion). Sudah jelas bahwa semua elmen dari bauran pemasaran atau mix marketing tadi secara sendirisendiri saling berkaitan dan saling dapat mengganti mengkompensasi (substitutable). Misalnya, suatu perusahaan yang ingin meningkatkan hasil penjualannya dapat sajah melakukan cara dengan menurunkan harga atau menambah jumlah tenaga penjaulannya, menaikan anggaran iklan atau promosi penjualannya. ${ }^{2}$

Etika dalam bisnis memang tidak bisa diabaikan begitu saja mengingat bisnis adalah suatu kegiatan yang berhubungan langsung dengan masyarakat dan bisnis merupakan suatu sistem dalam menawarkan barang atau jasa untuk memenuhi permintaan dan kebutuhan masyarakat. ${ }^{3}$ Etika bisnis Islam merupakan suatu proses dan upaya untuk mengetahui hal-hal yang benar dan salah yang selanjutnya tentu melakukan hal yang benar berkenaan dengan produk, pelayanan perusahaan dengan pihak yang berkepentingan dengan tuntutan perusahaan.

Menurut pengamatan penulis Perusahaan tahu yang ada di Desa Talaga Wetan terdiri dari 51 perusahaan. Rata-rata usaha yang mereka jalankan adalah sekala industri rumaha atau home industri. Banyaknya industri tahu tahu di Desa Talaga membuat perusahaan tahu Sari Rasa harus bisa mempertahankan perusahaannya dari para pesaing yaitu dengan menggunakan strategi pemasaran melalui Kebijakan penentuan harga, kebijakan pemilihan produk, kebijakan penentuan promosi yang paling efektif dan efisien, kebijakan pemilihan saluran distribusi yang paling tepat. Karena hal ini sangat mempengaruhi perilaku konsumen untuk membeli produk perusahaan yang akhirnya akan meningkatkan jumlah penjualan pada

${ }^{2}$ Philip Kotler, Manajemen Pemasaran, Analisis, Perencanaan dan Mengendalikan, Edisi Kelima, Jilid I (Jakarta: Erlangga, 1986), 419.

${ }^{3}$ Buchari Alma, Kewirausahaan (Bandung: Alfabeta, 2009), 238. 
perusahaan. Dalam hal ini perusahaan tahu Sari Rasa dituntut untuk mempunyai keunggulan yang berbeda dari pesaingpesaing usaha yang sama maupun pesaing lainnya. Persaingan tersebut juga menuntut adanya hubungan yang sangat kuat antara penjual dan pembeli. Penentuan tempat penelitian ini dilakukan secara sengaja dengan mempertimbangkan bahawa perusahaan Tahu Sari Rasa mampu mempertahankan kelangsungan hidupnya ditengah persaingan yang ketat. Untuk itu maka penulis merasa perlu untuk mengkaji lebih dalam lagi mengenai. 1) Bagaimana penerapan strategi pemasaran dalam meningkatkan penjualan di tinjau dari etika bisnis Islam? 2) Bagaimana strategi pemasaran pada perusahaan Tahu Sari Rasa ditinjau dari etika bisnis Islam?

\section{LITERATURE REVIEW}

Untuk menghindari pengulangan dalam penelitian ini, sehingga tidak terjadi adanya pembahasan yang sama dengan penelitian lain, maka penulis perlu menjelaskan adanya tujuan penelitian yang akan diajukan. Adanya beberapa tulisan yang berkaitan dengan masalah tersebut merupakan suatu data yang sangat penting. Berikut beberapa karya yang terdokumentasikan terkait permasalahan yang dikaji, yaitu pertama, jurnal Dimas Hendika Wibowo Zainul Arifin dengan judul analisis strategi pemasaran untuk meningkatkan daya saing UMKM (studi pada Batik Diajeng Solo) penelitian ini berfokus pada strategi pemasaran dalam meningkatkan daya saingan penelitian ini dilakukan di Batik Diajeng. ${ }^{4}$

Kedua, jurnal Arminsyurita dengan judul Analisis Strategi Pemasaran Jamur Rimba Jaya Mushroom. Penelitian ini

${ }^{4}$ Dimas Hendika Wibowo Zainul Arifin, "Analisis Strategi Pemasaran Untuk Meningkatkan Daya Saing UMKM", Jurnal Administrasi Bisnis, Vol. 29, No. 1 (Desember, 2015). bergerak di bidang industri agrobisnis dalam pengadaan sayur dan jamur. ${ }^{5}$

Dan ketiga, jurnal Aisyah Amalia dengan judul perencanaan strategi pemasaran dengan pendekatan bauran pemasaran dan swot pada perusahaan Popsy Tubby. Penelitian ini memiliki tujuan untuk mengetahui perencanaan strategi pemasaran Popsy Tubby dengan pendekatan bauran pemasaran dan SWOT. ${ }^{6}$

Dari beberapa penelitian diatas berbeda dengan penelitian penulis yang akan menganalisis strategi pemasaran dan tinjauan etika bisnis Islam pada wilayah home industri Tahu, khususnya perusahaan Tahu Sari Rasa. Pada penelitian ini penulis ingin mengetahui sejauh mana strategi pemasaran yang dilakukan oleh perusahaan home industri Tahu Sari Rasa dalam meningkatkan penjualannya meliputi produk, harga, distribusi dan promosi. Penulis juga mengamati etika bisnis Islam dalam strategi pemasaran pada perusahaan home industri Tahu Sari Rasa.

\section{METODELOGI PENELITIAN}

Metode penelitian yang digunakan oleh penulis adalah penelitian kualitatif. Penelitian kualitatif adalah penelitian yang bermaksud untuk memahami fenomena tentang apa yang dialami oleh subjek penelitian misalnya prilaku, persepsi, motivasi, tindakan, dan lain-lainya. Secara holistik dan dengan cara deskripsi dalam bentuk kata-kata dan bahasa, pada suatu konteks khusus yang alamiah dan dengan memanfaatkan berbagai metode alamiah. ${ }^{7}$ Penulis menggunakan pendekatan deskriftif. Penelitian deskriptif bertujuan untuk

\footnotetext{
${ }^{5}$ Arminsyurita, “Analisis Strategi Pemasaran Jamur Rimba Jaya Mushrom", Jurnal Ilmiah Ilmu Administrasi, Vol. IV, No. 2 (September, 2014).

${ }^{6}$ Aisyah Amalia, "Perencanaan Strategi Pemasaran Dengan pendekatan Bauran Pemasaran Popsy Tubby", Jurnal Manajemen dan Start-up Bisnis, Vol. 1, No. 3 (Agustus, 2016).

7 Lexy J. Moleong, Metode Penelitian Kualitatif, Cet. XXIV (Bandung: PT. Remaja Rosdakarya, 2007), 6.
} 
memberikan gambaran tentang suatu gejala atau suatu masyarakat tertentu. Pada penelitian jenis ini umumnya mendeskripsikan suatu permasalahan berdasarkan beberapa indikator yang dijadikan dasar penentuan adanya permasalahan atau tidak. Selain itu, penulis juga mecari kesesuaian antara penerapan strategi pemasaran dengan etika bisnis Islam pada perusahaan Tahu Sari Rasa.

Sumber data yang diperlukan adalah data primer dan data sekunder. Data primer didapatkan melalui wawancara dengan informan diantaranya pemegang perusahaan dan karyawan. Adapun data sekunder yang digunakan di sini yaitu, skripsi, jurnal, dan website yang berkaitan dengan strategi pemasaran dan etika bisnis Islam, beserta kantor Desa Talaga Wetan.

Teknik pengumpulan data merupakan langkah yang paling strategis dalam penelitian, karena tujuan utama dari penelitian adalah mendapatkan data. ${ }^{8}$ Metode observasi atau pengamatan adalah kegiatan keseharian manusia dengan menggunakan panca indera mata dan dibantu dengan panca indera lainnya. ${ }^{9}$ Teknik ini dilakukan dengan mengadakan pengamatan langsung terhadap objek yang akan diteliti sehingga didapatkan gambaran yang jelas mengenai objek yang akan diteliti. Metode wawancara/interview adalah proses memperoleh keterangan untuk tujuan penelitian dengan cara tanya jawab sambil bertatap muka antara pewancara dengan responden/orang yang diwawancarai, dengan atau tanpa menggunakan pedoman (guide) wawancara. ${ }^{10}$ Teknik ini digunakan untuk mengumpulkan data primer melalui wawancara langsung kepada responden berdasarkan daftar pertanyaan (kuisioner)

\footnotetext{
${ }^{8}$ Sugiono, Metode Penelitian Kuantitatif, Kualitatif dan $R$ \& D (Bandung: Alfabeta, 2013), 224.

${ }^{9}$ Burhan Bungin, Metodologi Penelitian Sosial (Surabaya: Airlangga University Press, 2001), 142. Sosial, 133.
}

yang telah dipersiapkan sebelumnya. yang telah disusun. Metode dokumentasi adalah metode pengumpulan data yang digunakan untuk menelusuri data historis. ${ }^{11}$ Adapun metode dokumen yang dimaksud dalam penelitian ini adalah buku-buku, catatancatatan, majalah-majalah, surat kabar, internet, koran.

Alasan kenapa peneliti menggunakan tiga data tersebut karena peneliti ingin menegetahui sedalam dan seluas mungkin informasi yang akan digali dilapangan guna mendapatkan data yang valid dan realiabel. Karena penelitian kualitatif lebih condong kepada ketajaman peneliti itu sendiri untuk mencari celah dan menjadikan sebuah kesimpulan yang berarti dan menjadi penemuan dan pengetahuan.

\section{KONSEP DASAR}

\section{Teori Strategi}

Strategi sering digunakan oleh perusahaanperusahaan dalam mencapai tujuannya, begitu juga dalam dunia bisnis. Biasanya istilah strategi digunakan dalam perang guna memenangkan pertempuran dengan lawannya, namun kali ini strategi juga dipergunakan oleh perusahaan dalam memasarkan produknya. Adapun pengertian strategi ada beberapa tokoh yang mengemukakan pendapat diantaranya :

Alfred Chandler mengemukakan strategi adalah penerapan sasaran dalam jangka panjang sebuah perusahaan, dan arah tindakan serta alokasi sumber daya yang di perlukan untuk mencapai sasaran dan tujuan itu. ${ }^{12}$

Stephanie K. Marrus strategi didefinisikan sebagai suatu proses penentuan cara pemimpin puncak yang berfokus pada tujuan jangka panjang organisasi, disertai penyusunan suatu cara

Sosial, 152.

${ }^{11}$ Burhan Bungin, Metodologi Penelitian

${ }^{12}$ Panji Anoraga, Manajemen

Bisnis

(Jakarta: PT. Asdi Mahasatya, 2004), 339. 
atau upaya bagaimana agar tujuan tersebut dapat dicapai. $^{13}$

Dari definisi di atas jelaslah sebuah perusahaan dalam menjalankan roda bisnisnya harus memiliki strategi yang harus dilakukan oleh sebuah perusahaan agar bisa tercapai sebuah tujuan perusahaan dengan baik, karena apabila sebuah perusahaan tidak memiliki strategi maka akan berakibat di setiap unit organisasinya akan kehilangan arah dan tujuan.

\section{Teori Pemasaran}

Menurut Kotler Pemasaran adalah suatu proses sosial dan manajerial yang didalam individu dan kelompok mendapatkan apa yang mereka butuhkan dan inginkan dengan menciptakan, menawarkan, dan mempertukarkan produk yang bernilai dengan pihak lain." 14

Menurut Boyd Pemasaran adalah suatu proses yang melibatkan kegiatan-kegiatan penting yang memungkinkan individu dan perusahaan mendapatkan apa yang mereka butuhkan dan inginkan melalui pertukaran dengan pihak lain. ${ }^{15}$

Pemasaran adalah kegiatan manusia yang diarahkan untuk memenuhi kebutuhan dan keinginan melalui proses pertukaran. Hal tersebut disebabkan karena pemasaran merupakan salah satu kegiatan perusahaan, dimana secara langsung berhubungan dengan konsumen. Maka kegiatan pemasaran dapat diartikan sebagai kegiatan manusia yang berlangsung dalam kaitan dengan pasar. ${ }^{16}$

Mengemukakan definisi pemasaran berarti bekerja dengan pasar sasaran untuk

\footnotetext{
${ }^{13}$ Husein Umar, Strategic Management in Action (Jakarta: PT. Gramedia Pustaka Utama, 2001), 31.

${ }^{14}$ Philip Kotler dan Armstrong, Dasar-dasar Pemasaran, Edisi Kesembilan (Jakarta: PT. Indeks, 2004), 7.

${ }^{15}$ Harper W. Boyd, Manajemen Pemasaran, Edisi Kedua (Jakarta: Erlangga, 2000), 4.

${ }^{16}$ Philip Kotler, et.al., Manajemen Pemasaran Sudut Pandang Asia (Jakarta: PT. Indeks, 2004), 12.
}

mewujudkan pertukaran yang potensial dengan maksud memuaskan kebutuhan dan keinginan manusia. Sehingga dapat dikatakan bahwa keberhasilan pemasaran merupakan kunci kesuksesan dari suatu perusahaan.

\section{Konsepsi Pemasaran}

Konsep pemasaran menyebutkan bahwa kunci untuk mencapai tujuan organisasi jika perusahaan itu lebih efektif dari pada pesaingnya dengan menciptakan, menyerahkan, dan mengkomunikasikan manfaat pelanggan yang lebih unggul bagi pasar sasaran yang dipilihnya. ${ }^{17}$

Konsep pemasaran berbeda dengan tiga konsep yang dinyatakan di atas. Konsep ini berorientasikan memenuhi keperluan dan kemahuan dan efektif, sedangkan tiga konsep sebelumnya berorientasikan kepentingan industri untuk menjual produk. Konsep pemasaran terdiri dari empat pilar yaitu: ${ }^{18}$ Pertama, pasar sasaran: perusahaan bisa melakukan yang terbaik jika mereka memilih pasar sasaran dengan hati-hati dan mempersiapkan program pemasaran yang sesuai. Kedua, kebutuhan pelanggan: setelah perusahaan menentukan pasar sasarannya, mereka harus memahami kebutuhan pelanggan.

Ketiga, pemasaran terpadu: pada saat semua departemen di sebuah perusahaan bekerja sama untuk melayani kepentingan pelanggan, hasilnya berupa pemasaran terpadu. Kempat, Profitabilitas: tujuan terpenting dari konsep pemasaran adalah membantu organisasi untuk mencapai tujuan. Bagi perusahaan swasta, tujuan utamanya adalah kemampuan untuk memperoleh keuntungan secara terusmenerus dalam jangka panjang, bagi organisasi nirlaba dan kemasyarakatan, tujuannya adalah bertahan dan menarik

\footnotetext{
${ }^{17}$ Philip Kotler, Edisi Kelima Manajemen Pemasaran, Analisis, Perencanaan dan Mengendalikan, 30.

${ }^{18}$ Philip Kotler, et.al., Manajemen Pemasaran Sudut Pandang Asia, 29.
} 
cukup banyak dana untuk menjalankan pekerjaan yang bermanfaat.

Jadi dalam menentukan pemasaran seseorang penjual harus berusaha menawarkan kepada calon pembali supaya tertarik dengan produk yang ditawarkan itu, dengan begitu kalau pembeli itu sudah tertarik dengan produk yang ditawarkan maka pembeli itu akan membeli produk yang ditawarkan oleh penjual itu.

\section{Pemasaran Syariah}

Pemasaran Syari'ah adalah sebuah disiplin bisnis strategi yang mengarahkan proses penciptaan, penawaran dan perubahan value dari suatu inisiator kepada stakeholder, yang didalam keseluruhan prosesnya sesuai dengan akad dan prinsip-prinsip muamalah (bisnis) dalam Islam. ${ }^{19}$ Ini artinya bahwa Syari'ah marketing, seluruh proses baik proses penciptaan, proses penawaran, maupun proses perubahan nilai (value), tidak boleh ada hal-hal yang bertentangan dengan akad dan prinsip-prinsip muamalah yang Islami. Sepanjang hal tersebut dapat dijamin, dan penyimpangan prinsip-prinsip muamalah Islami tidak terjadi dalam suatu transaksi dalam pemasaran dapat dibolehkan.

Nabi Muhammad menunjukan bagaimana cara berbisnis yang berpegang teguh pada kebenaran, kejujuran dan sikap amanah sekaligus bisa tetap memperoleh keutungan yang optimal. $^{20}$ Dengan berpegang teguh pada nilai-nilai yang terdapat dari Al-Qur'an dan Hadits, Nabi Muhammad melakukan bisnis secara profesional. Nilai-nilai tersebut menjadi suatu landasan yang dapat mengarahkan untuk tetap dalam koridor yang adil dan benar. Landasan aturan-aturan inilah yang

\footnotetext{
${ }^{19}$ Hermawan Kertajaya dan Muhammad Syakir Sula, Syari'ah Marketing (Bandung: Mizan, 2006), 139.

${ }^{20}$ Muhammad Syakir Sula dan Hermawan Karta Jaya, Marketing Syari'ah, 26.
}

menjadi suatu syari'ah atau hukum dalam melakukan suatu bisnis. $^{21}$

\section{Konsep Strategi Pemasaran}

Strategi pemasaran merupakan strategi yang melayani pasar atau segmen pasar yang di jadikan target oleh perusahaan. Definisi strategi pemasaran adalah sebagai berikut ; "strategi pemasaran adalah logika pemasaran yang digunakan oleh perusahaan dengan harapan agar unit bisnis dapat mencapai target perusahaan". ${ }^{22}$ Strategi Pemasaran adalah pendekatan pokok yang akan digunakan oleh unit bisnis dalam mencapai sasaran yang telah ditetapkan lebih dulu, di dalamnya tercantum keputusan-keputusan pokok mengenai target pasar, penetapan produk di pasar, bauran pemasaran dan tingkat biaya pemasaran yang diperlukan. $^{23}$

Merancang strategi pemasaran yang kompetitif dimulai dengan melakukan analisis terhadap pesaing. Perusahaan membandingkan nilai dan kepuasan pelanggan dengan nilai yang diberikan oleh produk, harga, promosi dan distribusi (marketing mix) terhadap pesaing dekatnya.

Strategi pemasaran pada dasarnya memberikan arah dalam kaitannya dengan variabel-variabel seperti segmentasi pasar, identifikasi pasar sasaran, positioning, elemen bauran pemasaran dan biaya bauran pemasaran. Strategi pemasaran merupakan bagian integral dari strategi bisnis yang memberikan arah pada semua fungsi manajemen suatu organisasi. Adapun variabel-variabel mix marketing dapat diuraikan sebagai berikut : ${ }^{24}$ Pertama, Produk (Product) Kebijakan umum untuk penetapan merk, pemosisian, modifikasi,

\footnotetext{
${ }^{21}$ Muhammad Syakir Sula dan Hermawan Karta Jaya, Marketing Syari'ah, 27.

${ }^{22}$ Philip Kloter \& Gary Armstrong, Principles of Marketing (Nith Edition), Prentice Hall (New Jersey: Upper Saddle River, 2001), 76.

${ }^{23}$ Philip Kotler, Edisi Kelima Manajemen Pemasaran, 401.

${ }^{24}$ Fandi Tjiptono, Strategi Pemasaran (Yogyakarta: Penerbit Andi Offset, 1995), 35.
} 
penambahan, desain dan pengepakan produk. Produk merupakan elemen penting sebab dengan inilah perusahaan berusaha untuk memenuhi kebutuhan dan keinginan dari konsumen, namun keputusan itu tidak berdiri sendiri sebab produk atau jasa sangat erat hubungannya dengan target market yang dipilih.

Kedua, Harga (Price) Kebijakan umum harga yang harus diikuti oleh grup produk dalam segmen pasar. Harga suatu produk atau jasa ditentukan dari besarnya pengorbanan yang dilakukan untuk menghasilkan jasa tersebut dan laba atau keuntungan yang diharapkan. Oleh karena itu, penentuan harga produk dari suatu perusahaan merupakan masalah yang penting bagi perusahaan.

Ketiga, Distribusi (Place) Kebijakan umum untuk saluran distribusi dan tingkat layanan konsumen. Setelah perusahaan berhasil menciptakan barang atau jasa yang dibutuhkan dan menetapkan harga yang layak, tahap berikutnya menentukan metode penyampaian produk ke pasar melalui ruterute yang efektif hingga tiba pada tempat yang tepat, dengan harapan produk tersebut berada ditengah-tengah kebutuhan dan keinginan konsumen yang membutuhkan produk tersebut. Masalah pemilihan saluran distribusi adalah masalah yang berpengaruh bagi marketing, karena kesalahan dalam memilih dapat menghambat bahkan memacetkan usaha penyaluran produk dari produsen ke konsumen.

Kempat, Promosi (Promotion) Kebijakan umum untuk berkomunikasi dengan konsumen melalui beberapa cara antara lain periklanan (advertising), penjualan pribadi (personal selling), promosi penjualan (sales promotion) dan publisitas (publicity).

\section{Konsep Penjualan}

Aktivitas penjualan merupakan pendapatan utama perusahaan karena jika aktivitas penjualan produk maupun jasa tidak dikelola dengan baik maka secara langsung dapat merugikan perusahaan. Dapat disebabkan karena sasaran penjualan yang diharapkan tidak tercapai dan pendapatan pun akan berkurang. Defenisi penjualan sangat luas. Beberapa ahli menyebutkan sebagai ilmu dan beberapa yang lain menyebut sebagai seni, adapula yang memasukkan masalah etika dalam penjualan. Pada pokoknya istilah menjual dapat diartikan sebagai berikut : menjual adalah ilmu dan seni mempengaruhi pribadi yang dilakukan oleh penjual untuk mengajak orang lain agar bersedia membeli barang atau jasa yang ditawarkannya. ${ }^{25}$

\section{Faktor-faktor yang Mempengaruhi Penjualan}

Dalam praktek penjualan itu dipengaruhi oleh beberapa faktor, seperti yang dikemukakan oleh Basu Swastha DH sebagai berikut; kondisi dan kemampuan penjual, kondisi pasar, kondisi organisasi perusahaan, modal dan faktor lain. ${ }^{26}$ Pertama, Kondisi dan Kemampuan Penjual. Transksi jual-beli atau pemindahan hak milik secara komersial atas barang dan jasa itu pada prinsipnya melihatkan dua pihak, yaitu penjual sebagai pihak pertama dan pembeli sebagai pihak kedua. Di sini, penjual harus meyakinkan kepada pembelinya agar dapat berhasil mencapai sasaran penjualan yang diharapkan.

Kedua, Kondisi Pasar, sebagai kelompok pembeli atau yang menjadi sasaran dalam penjualan, dapat pula mempengaruhi kegiatan penjualannya. Dan ketiga, Modal, Akan lebih sulit bagi penjual untuk menjual barangnya apabila barang yang dijual tersebut belum dikenal oleh calon pembelinya atau apabila lokasi pembeli jauh dari tempat penjual. Dalam keadaan seperti ini, penjual harus memperkenalkan terlebih dahulu atau membawa barangnya ke tempat pembeli.

\footnotetext{
${ }^{25}$ Basu Swashta, Manajemen Pemasaran Modern (Yogyakarta: Liberty, 1999), 5.

${ }^{26}$ Basu Swastha, Manajemen Penjualan, Edisi 3 (Yoyakarta: BPFE Universitas Gadjah Mada, 1998), 29.
} 
Untuk melaksanakan maksud tersebut diperlukan adanya saran serta usaha, seperti alat transportasi, tempat peragaan baik didalam perusahaan maupun di luar perusahaan, usaha promosi dan sebagainya. Keempat, Kondisi Organisasi Perusahaan, Pada perusahaan besar, biasanya masalah penjualan ini ditangani oleh bagian tersendiri (bagian penjualan) yang dipegang orang-orang tertentu atau ahli dibidang penjualan. Lain halnya perusahaan kecil dimana masalah penjualan ditangani oleh orang yang juga melakukan fungsi lain. Hal ini disebabkan karena jumlah tenaga kerjanya lebih sedikit, sistem organisasinya lebih sederhana, masalah-masalah yang dihadapi serta sarana yang dimilikinya juga tidak jumlah tenaga kerjanya lebih sedikit, sistem organisasinya lebih sederhana, masalah-masalah yang dihadapi serta sarana yang dimilikinya juga tidak sekompleks perusahaan besar. Biasanya masalah penjualan ini ditangani sendiri oleh pimpinan dan tidak diberikan kepada orang lain.

Kelima, Faktor-faktor lain, seperti : periklanan, peragaan, kampanye, pemberian hadiah, sering mempengaruhi penjualan. Namun untuk melaksanakannya, diperlukan sejumlah dana yang tidak sedikit. Bagi perusahaan yang bermodal kuat, kegiatan ini secara rutin dapat dilakukan. Sedangkan bagi perusahaan yang kecil yang mempunyai modal relatif kecil, kegiatan ini lebih jarang dilakukan. Ada penguasaha yang berpegang pada suatu prinsip bahwa paling penting membuat barang yang baik.

\section{Kegiatan Penjualan Ditinjau Menurut Pandangan Ekonomi Islam}

Sistem perekonomian Islam saat ini lebih dikenal dengan fiqh mu'amalah. Fiqh mu'amalah adalah aturan-aturan (hukum) Allah yang ditujukan untuk mengatur kehidupan manusia dalam urusan kehidupan atau urusan yang berkaitan dengan urusan duniawi sosial kemasyarakatan. ${ }^{27}$ Anjuran untuk melakukan kegiatan penjualan atau perdagangan dijelaskan didalam al-Qur'an surat al-Baqharah ayat 198 yang berbunyi sebagai berikut:

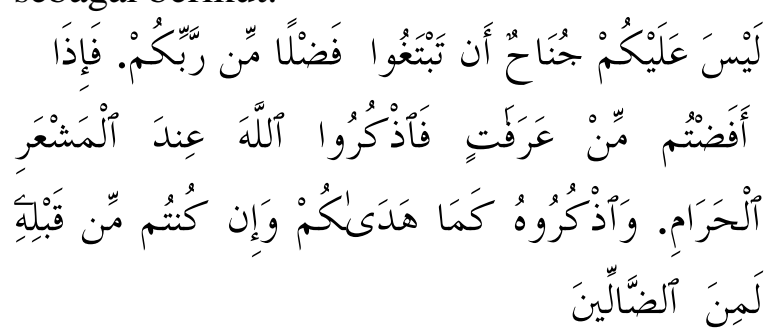

Artinya: Tidak ada dosa bagimu untuk mencari karunia (rezeki hasil perniagaan) dari Tuhanmu. Maka apabila kamu telah bertolak dari 'Arafat, berdzikirlah kepada Allah di Masy'arilharam. Dan berdzikirlah (dengan menyebut) Allah sebagaimana yang ditunjukkan-Nya kepadamu; dan sesungguhnya kamu sebelum itu benar-benar termasuk orangorang yang sesat. ${ }^{28}$

Keterangan Al-Qur'an surat AlBaqharah ayat198 diatas dijelaskan bahwa Allah SWT menyeru manusia untuk berusaha mencari rizki yang halal. Salah satu cara memperoleh rezki dari Allah SWT yaitu dengan melakukan perdagangan atau berusaha. Melakukan transaksi jual-beli boleh melakukan khiyar selama mereka belum berpisah. Jika keduanya melakukan transaksi dengan benar dan jelas, keduanya diberkahi dalam jual-beli mereka. Jika mereka menyembunyikan dan berdusta, Allah SWT akan memusnahkan keberkahan jual-beli mereka. Karena itu dalam dunia perdagangan, Islam mengajarkan agar para pihak bertindak jujur. Kejujuran dalam jualbeli ini menempatkan mereka yang melakukan transaksi pada tempat baik dan mulia dalam pandangan Allah Swt.

\footnotetext{
${ }^{27}$ Rachmat Syafe'i, Fiqh Mu'amalah, (Bandung: CV. Pustaka Setia, 2004), 15.

${ }^{28}$ QS. Al-Baqharah (2): 198.
} 


\section{Konsep Etika Bisnis Menurut Hukum Islam}

Islam merupakan agama yang komprehensif dan universal. Dikatakan komprehensif, karena Islam mengatur seluruh aspek kehidupan manusia. Universal karena daya berlakunya tidak terbatas oleh waktu dan tempat. Masalah bisnis, perdagangan, atau perniagaan, atau perekonomian merupakan salah satu bidang muamalah. ${ }^{29}$ Islam adalah agama yang sangat luar biasa. Islam agama yang lengkap, yang berarti mengurusi semua hal dalam hidup manusia. Islam agama yang mampu menyeibangkan dunia dan akhirat, antara hablum minallah (hubungan dengan Allah) dan hablum minannas (hubungan sesama manusia). Ajaran Islam lengkap karena Islam agama terakhir sehingga harus mampu memecahkan berbagai masalah besar manusia.

Dalam kehidupan haruslah seimbang, baik dunia dan akhirat. Seperti ajaran Islam yang menyeimbangkan dunia dan akhirat. Seperti yang tertulis di dalam al-Qur'an di surat al-Jumu'ah ayat 10:

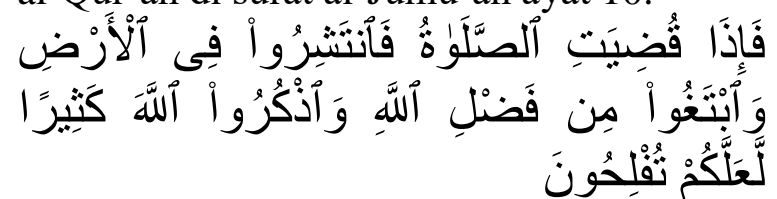

Artinya: Apabila telah ditunaikan shalat, maka bertebaranlah kamu di muka bumi; dan carilah karunia Allah dan ingatlah Allah banyakbanyak supaya kamu beruntung. ${ }^{30}$

Sesuai dari ayat diatas dikatakan bahwa apabila telah menjalankan shalat perintah dari Allah Swt maka akan bertebaran rezeki pada umat manusia. Saat sedang melakukan pemasaran maka akan berhubungan dengan sesama manusia, itulah mengapa kita harus menjaga silaturahmi terhadap sesama manusia dan mengajarkan

\footnotetext{
${ }^{29}$ Neni Sri Imaniyati, Hukum Ekonomi dan Ekonomi Islam (Bandung: Mandar Maju, 2002), 168.

${ }^{30} \mathrm{QS}$. Al-Jumu'ah (62):10.
}

shalat (mengingat Allah) agar bertebaran rezeki di muka bumi.

\section{Nilai Dasar Etika Bisnis Islam}

Etika bisnis Islam merupakan bisnis yang mengedepankan nilai-nilai al-Qur'an. Oleh karena itu, bebrapa nilai dasar dalam etka bisnis Islam yang disarikan dari inti sari ajaran Islam itu sendiri adalah, antara lain :31 Pertama, Kesatuan (Tauhid/unity) dalam hal ini adalah kesatuan sebagaimana terefleksikan dalam konsep tauhid yang memadukan keseluruh aspek-aspek kehidupan muslim baik dalam bidang ekonomi, politik, sosial menjadi keseluruhan yang homogen, serta mementingkan konsep konsistensi dan keteraturan yang menyeluruh. Kedua, Keseimbangan (equilibrium/adil) Islam sangat menganjurkan untuk berbuat adil dalam berbisnis, dan melarang berbuat curang atau berlaku dzalim. Rasulullah aiutus Allah untuk membangun keadilan. Kecelakaan besar bagi yang berbuat curang, yaitu orang-orang yang apabila menerima takaran dari orang lain meminta untuk dipenuhi, sementara kalau menakar atau menimbang untuk orang selalu dikurangi.

Keempat, Kebebasan merupakan baigian penting dalam nilai etika bisnis Islam, tetapi kebebasan itu tidak merugikan kepentingan kolektif, kepentingan individu dibuka lebar. Tidak adanya ada batasan pendapat bagi seseorang mendorong manusia untuk aktif berkarya dan bekerja dengan segala potensi yang dimilikinya. Kelima, tanggung jawab (responsibility) Kebebasan tanpa batas adalah suatu hal yan mustahil dilakukan oleh manusia karena tidak menuntut adanya pertanggung jawaban dan akuntabilitas. Untuk memenuhi tuntunan keadilan dan kesatuan, manusia perlu mempertanggung jawabkan tindakannya secara logis prinsip ini berhubungan erat dengan kehendak bebas. Ia menetapkan batasan mengenai apa yang bebas dilakukan oleh manusia dengan

${ }^{31}$ Abdul Aziz, Etika Bisnis Perspektif Islam (Bansung: Alfabeta, 2013), 45-46. 
bertanggung jawab atas semua yang dilakukannya.

Keenam, Kebenaran (kebijakan dan kejujuran) Kebenaran dalam konteks ini selai mengandung makna kebenaran lawan dari kesalahan, mengandung pila dua unsur yaitu kebajikan dan kejujuran. Dalam konteks ini bisnis kebenaran dimaksudkan sebagai niat, sikap dan prilaku benar meliputi proses akad (transaksi) proses mencari atau memperoleh komoditas pengembangan maupun dalam proses upaya meraih atau menetapkan keuntungan.

\section{PEMBAHASAN DAN DISKUSI Penerapan Strategi Pemasaran dalam Meningkatkan Penjualan}

Dalam pemasaran, pemilik perusahaan tidak hanya memikirkan keuntungan atau laba saja tetapi harus memikirkan bagaimana cara mendapatkan laba tersebut dan bagaimana penerapan strategi supaya perusahaan bisa bertahan di dalam persaingan antara perusahaan lainya yang sejenis. Dengan seperti itu pemilik perusahaan dituntunt untuk memahami strategi pemasaran. Seperti yang dikutip dari buku Philip Kotler edisi kelima manajemen pemasaran jilid I, strategi pemasaran adalah pendekatan pokok yang akan digunakan oleh unit bisnis dalam mencapai sasaran yang telah ditetapkan lebih dulu, didalamnya tercantum keputusan-keputusan pokok mengenai target pasar, penetapan produk di pasar, bauran pemasaran dan tingkat biaya pemasaran yang diperlukan.

Kombinasi dari beberapa variabel atau kegiatan pemasaran itulah yang merupakan inti dari sistem pemasaran. Menurut Neil Borden dalam artikelnya berjudul "The concept of the marketing mix" yang diterbitkan di Journal of adverting research di tahun 1964. Bauran pemasaran adalah seperangkat alat pemasaran yang digunkan oleh perusahaan untuk mengejar tujuan pemasarannya. ${ }^{32}$

\footnotetext{
${ }^{32}$ Fandi Tjiptono, Strategi Bauran
}

Hingga saat ini model bauran pemasaran masih tetap paling populer dan menjadi elmen kunci dalam sebagian besar literatur pemasaran. Adapun strategi pemasaran yang dilakukan perusahaan Tahu Sari Rasa dalam meningkatkan penjualan akan dianalisis menggunakan empat variabel dengan konsep bauran pemasaran (mix marketing) yaitu : Pertama, Produk. Perusahaan Tahu Sari Rasa selalu mengedapankan kualitas produk, sehingga menciptakan rasa yang terbaik dan unggul diantara perusahaan tahu lainya. Karena, yang dibutuhkan oleh pasar atau konsumen adalah kualitas dari produk tahu tersebut. Produk yang ditawarkan perusahaan Tahu Sari Rasa beraneka ragam mulai dari tahu goreng, tahu bumbu, tahu mentah kuning, tahu mentah putih, kerupuk tahu dan menerima pesanan untuk anekan masakan dari tahu untuk acara hajatan. Dengan banyaknya pilihan produk tahu pada perusahaan Tahu Sari Rasa, membuat konsumen tidak merasa bosan dengan produk yang itu-itu saja dalam hal ini perusahaan Tahu Sari Rasa tidak memproduksi satu macam olahan tahu melainkan banyak varian dari olahan tahu. Perusahaan Tahu Sari Rasa selain memberikan beraneka ragam produk tahu, kualitas produk dan keunikan pun sangat diperhatikan oleh perusahaan tersebut, karena kualitas produk dan keunikan sangat membantu untuk meningkatkan penjualan pada perusahaan Tahu Sari Rasa.

Kedua, Promosi. Model promosi yang dilakukan oleh perusahaan Tahu Sari Rasa adalah dengan cara pemasaran langsung dan promosi penjualan : Pertama, pemasaran langsung yaitu dengan melalui pengecer atau pedagang gendong. Ada 5 orang pedagang gendong yang langsung datang ke pabrik dengan dengan tujuan tempat yang berbeda-beda dan pengecer yang di pasar Talaga ada 15 orang pengecer dengan tujuan tempat yang berbeda-beda juga. Jadi total pelanggang pengecer perusahaan Tahu Sari Rasa adalah 20 orang, belum dengan konsumen yang datang 
membeli untuk dijadikan oleh-oleh dan konsumen untuk kebutuhan makanan seharihari. Kedua, promosi penjualan dengan tujuan untuk meningkatkan penjualan atau meningkatkan jumlah pelanggan. Promosi penjualan dilakukan untuk menarik perhatian konsumen atau pelanggan membeli produk yang ditawarkan oleh perusahaan Tahu Sari Rasa. Untuk promosi penjualan pada perusahaan Tahu Sari Rasa yaitu memberikan hadiah setiap satu tahun sekali pada saat perayaan Hari Idul Fitri yaitu berupa pakaian atau uang tunai. Apabila konsumen membeli setiap hari diatas Rp. 20.000. Model promosi yang dilakukan seperti itu sudah merasa cukup untuk meningkatkan penjualan pada perusahaan Tahu Sari Rasa. Karena hanya menggunakan personal selling dan promosi penjualan, maka penjualan produk tidak akan maksimal. Tetapi, apabila perusahaan Tahu Sari Rasa menggunakan promosi melalui media masa, seperti pemasangan iklan di internet, radio, pemasangan papan iklan dijalan dan mengikuti kegiatan bazar. Sehingga dengan seperti itu pembeli akan merasa penasaran untuk pembeli produk tahu dari perusahaan Tahu Sari Rasa dan dikenal oleh masyarakat luas.

Ketiga, Harga. Kotler dan Keller menjelaskan harga merupakan salah satua bagian yang sangat penting dalam pemasaran suatu produk karena harga adalah satu dari empat bauran pemasaran. Harga adalah suatu nilai tukar dari produk barang maupun jasa yang dinyatakan dalam satuan moneter. Harga juga merupakan salah satu penentu keberhasilan suatu perusahaan karena harga menentukan seberapa besar keuntungan yang akan diperoleh perusahaan dari penjualan produknya baik berupa barang maupun jasa. $^{33}$ Harga jual produk tahu pada perusahaan Tahu Sari Rasa sangat terjangkau untuk masyarakat, harga tahu

\footnotetext{
${ }^{33}$ Philip Kotler dan Kevin Lane Keller, Manajemen Pemasaran, Edisi ke Tigabelas Jilid 2 (Jakarta : Erlangga, 2009), 67.
}

pada perusahaan Tahu Sari Rasa bisa disesuaikan dengan harga yang telah ada sehingga produk tahu yang dijual ini dengan mudah dapat diterima oleh masyarakat, patokan harga jual tahu Sari Rasa mulai dari Rp 200,- sampai 8.00,- perbiji. Dengan seperti ini terjangkaunya harga jual produk tahu dapat membantu dalam meningkatkan penjualan pada perusahaan Tahu Sari Rasa.

Keempat, Distribusi. Distribusi adalah suatu jalur yang dilalui oleh arus barng dari produsen ke perantara dan akhirnya sampai pada pemakai. Distribusi merupakan masalah lain yang akan dihadapi perusahaan pada saat produk selsai diproses. Distribusi menyangkut cara penyampaian produk ketangan konsumen. Manajemen pemasaran mempunyai peran dalam mengevaluasi penampilan para penyalur. Bila perusahaan merencanakan suatu pasar tentu, yang pertama kali dipikirkan adalah siapa yang akan dituju sebagai penyalur di sana, atau berapa banyak yang bersedia untuk menjadi penyalur daerah tersebut. ${ }^{34}$ Perusahaan Tahu Sari Rasa melakukan dua cara saluran distribusi yaitu distribusi langsung dan distribusi tidak langsung. Diantarnya : 1)Distribusi langsung adalah sebuah sistem distribusi yang dilakukan oleh langsung oleh perusahaan kepada konsumennya. Perusahaan Tahu Sari Rasa menjualnya langsung kepada konsumen. Biasanya para konsumen langsung datang kepabrik untuk membeli produk tahu. Karena apabila konsumen langsung datang ke pabirik akan mendapatkan harga yang lebih murah di bandingkan membeli ke pengecer. 2) Distribusi tidak langsung ini menggunakan jasa distributor atau pengecer dalam pemasaran barangnya ke tangan konsumen. Hampir seluruh penjualan produk tahu pada perusahaan Tahu Sari Rasa yaitu melalui pengecer. Dengan seperti itu akan membantu proses pada penjualan.

\footnotetext{
${ }^{34}$ Doni Hariadi, "Pengaruh Produk, Harga, Promosi dan Distribusi terhadap Keputusan Pembelian", Jurnal Ilmu dan Riset Manajemen (2012): 2-3.
} 


\section{Strategi Pemasaran pada Perusahaan Tahu Sari Rasa Ditinjau dari Etika Bisnis Islam}

Etika pemasaran dalam Islam memiliki prinsip yang menjaga aturan dalam hukum Islam atau aturan hukum ekonomi syariah, pemasaran dalam Islam harus mengandung pemasaran syariah, yakni pemasaran yang selalu memperhatikan aturan dan tujuan ekonomi Islam. Akan lebih baik jika selaku seorang bisnis memperhatikan norma yang berlaku atau tata cara dagang yang ada dalam Islam, adanya tata cara berdagang atau berbisnis sudah diatur dalam al-Qur'an, selain itu sebagai pembisnis harus tahu apa saja bahaya yang mengintai dalam berbisnis. $^{35}$

Perusahaan Tahu Sari Rasa dalam penjualannya selalu menghargai dan adil kepada setiap konsumennya, tidak membedakan antara ras, suku, agama dan lain-lainya. Allah mencintai orang-orang yang berbuat adil karena berbuat adil akan mendekatkan diri kita kepada Allah SWT. Hal ini sebagaimana dijelaskan dalam surat Al-Maidah ayat 8, yaitu:

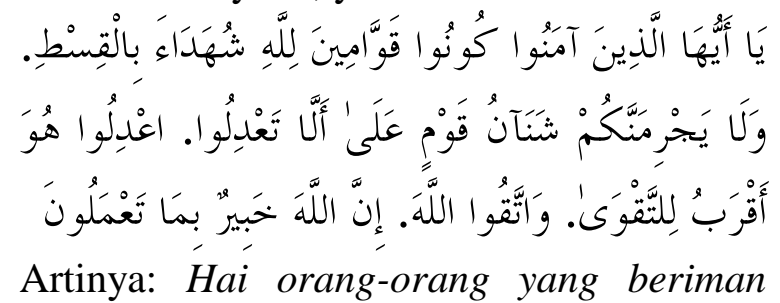
hendaklah kamu jadi orang-orang yang selalu menegakkan (kebenaran) karena Allah, menjadi saksi dengan adil. Dan janganlah sekali-kali

kebencianmu terhadap sesuatu kaum, mendorong kamu untuk berlaku tidak adil. Berlaku adillah, karena adil itu lebih dekat kepada takwa. Dan bertakwalah kepada Allah, sesungguhnya Allah Maha

\footnotetext{
${ }^{35}$ https://dalamislam.com/hukumislam/ekonomi/etika-pemasaran-dalam-islam. Diakses pada tanggal 17 Desember 2017.
}

\section{Mengetahui apa yang kamu kerjakan". 36}

Berikut strategi pemasaran pada perusahaan Tahu Sari Rasa ditinjau dari etika bisnis Islam : Produk, Pada perusahaan Tahu Sari Rasa memberikan kejujuran pada produk, tidak mencampuri antara produk yag kualitas baik dengan tidak baik. Karena pada prinsipnya perusahaan Tahu Sari Rasa tidak ingin mengecewakan para pembelinya atau konsumen.

Harga, Tidak diperbolehkannya pembatasan harga komoditi dimasa Muhammad SAW merupakan cermin pemikiran yang mewakili konsep harga. Muhammad SAW dalam (HR. Bhukhori, dari Abdullah bin Umar Ra.) bersabda : "janganlah kamu menjual menyaingi penjualan saudaramu” Konsep persaingan yang sehat dalam menentukan harga sudah ditekankan oleh Muhammad SAW. ${ }^{37}$ Konsep harga yang ditentukan oleh penjualan perusahaan Tahu Sari Rasa sesuai dengan sabda Nabi Muhammad SAW diatas, bahwa harga jual antara perusahaan Tahu Sari Rasa dengan perusahaan lainnya sama, tidak membedakan dengan yang lainnya dalam artian tidak menurunkan dari harga pasaran. Karena dengan seperti itu akan menjatukan perusahaan lain. Meskipun penjualan akan meningkat tetapi hasil penjualan tidak akan berkah. Mereka lebih menekankan penjualan bersaing di wilayah kualitas dan rasa tidak memper masalahkan harga.

Promosi, Nabi Muhammad SAW menekankan agar tidak melakukan sumpah palsu. Dinamakan sumpah palsu menurut beliau adalah usaha yang dilakukan untuk melansirkan barang dagangannya lagi berusaha dengan cara yang tercela. Sebagaimana firman Allah dalam surat alShu'ara ayat 181, yaitu:

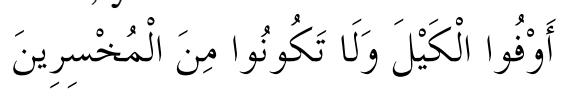

\footnotetext{
${ }^{36}$ QS. Al-Maidah (5): 8.

${ }^{37}$ Yayasan Penyelenggara Penterjemah/Pentafsiran al-Qur'an, al-Qur'an dan Terjemahannya, Departemen Agama RI, 2006, 604.
} 
Artinya: Sempurnakanlah takaran dan janganlah kamu termasuk orang-orang yang merugikan. ${ }^{38}$

Tidak dibolehkan pedagang melakukan pencampuran antara barang yang berkualitas baik dengan yang tidak baik. Perusahaan Tahu Sari Rasa selalu memberikan produk yang terbaik dan aman dikonsumsi untuk konsumen atau pelanggannya dalam setiap pemesanan produk.

Distribusi, Keadilan distribusi adalah prinsip utama dalam ekonomi Islam. Sistem ekonomi Islam sangat menghendaki bahwa dalam distribusi harus didasarkan pada dua sendi, yaitu kebebasan dan keadilan. Kebebasan disni adalah kebebasan yang dibingkai oleh nilai-nilai tauhid dan keadilan, tidak seperti kaum kapitalis, menyatakan sebagai tindakan membebaskan manusia untuk berbuat dan tidak berbuat tanpa campur tangan pihak mana pun, tetapi sebagai keseimbangan antara individu dengan unsur materi dan spiritual yang dimilikinya, keseimbangan antara individu dan masyarakat serta antara suatu masyarakat dengan masyarakat lainnya. ${ }^{39}$ Pendistribusian harta yang tidak adil dan merata akan membuat orang yang kaya bartambah kaya dan yang miskin semakin miskin. Dengan demikian, pola distribusi harus mendahulukan aspek prioritas berdasakan penilaian need assessment. Perusahaan Tahu sari Rasa tidak hanya sekedar mengejar keuntungan sebanyakbanyaknya, tapi menumbuhkan sikap tolong menolong, seperti membantu warga sekitar untuk bekerja pada perusahaan tersebut, sebagai implikasi sosial kegiatan bisnis dan menolong masyarakat sekitar untuk menjadi distributor atau pengecer produk tahu pada perusahaan Tahu Sari Rasa.

Dari analisis diatas menunjukan bahwa perusahaan Tahu Sari Rasa dalam faktor-faktor pendorong dalam

\footnotetext{
${ }^{38}$ QS. Al-Shu'ara (26): 181.

${ }^{39}$ Yusuf al-Qardhawi, Norma dan Etika Ekonomi Islam (Jakarta: Gema Insani Press, 1997), 201.
}

meningkatkan penjualan baik dari faktor dan internal. Faktor yang berasal dari internal adalah produk yang diolah perusahaan Tahu Sari Rasa mempunyai kualitas yang baik dan aman untuk dikonsumsi oleh masyarakat dan keanekaragaman produk tahu yang diciptakan oleh karena itu konsumen mersa sangat puas dengan perusahaan Tahu Sari Rasa dan harga jual produk tahu yang murah sehingga dapat terjangkau oleh masyarakat dan dibantunya penjualan produk tahu oleh para pengecer membantu untuk meningkatkan penjualan. Dari faktor eksternal peluang bagi langkah dalam mengembangkan bisnis

Beberapa faktor yang menghambat pemasarannya, yakni promsi yang digunakan masih tradisional, belum ada pemasaran yang sistematis sehingga distribusinya kurang maksimal karena hanya melayani konsumen tetap tidak ada perkembangan yang signifikan. Disamping itu perusahaan Tahu Sari Rasa masih kesulitan akses terhadap permodalan, kurangnya jaringan penjualan, banyaknya para pesaing, rendahnya produktifitas.

Islam telah menunjukan muamalah yang baik dalam berdagang. Allah SWT berfirman dalam al-Qur'an agar berdagang agar tidak hanya hanya mendapatkan keuntungan dan tidak merugikan dengan yang lainnya dalam surat al-Baqarah ayat 42, yaitu:

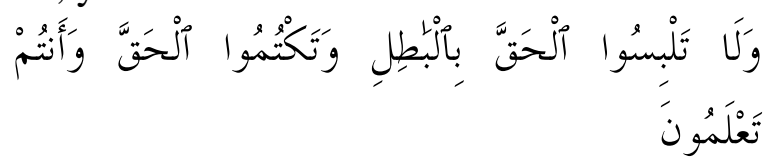

Artinya: Dan janganlah kamu campur adukkan yang hak dengan yang bathil dan janganlah kamu sembunyikan yang hak itu, sedang kamu mengetahui. ${ }^{40}$

Perusahaan Tahu Sari Rasa dalam bisnisnya sudah sesuai dengan etika bisnis Islam, terbukti dalam memasarkan produknya selalu mengedepankan kejujuran, ke adilan, transparan, tolong menolong,

\footnotetext{
${ }^{40}$ QS. Al-Baqarah (2): 42.
} 
hubungan yang baik dengan pelanggan atau konsumennya.

\section{KESIMPULAN}

Berdasarkan analisis penelitian yang dilakukan, maka dapat ditarik dua kesimpulan, yaitu pertama, konsep strategi bauran pemasaran atau mix marketing digunakan untuk melihat sejauh mana penerapan pemasaran pada perusahaan Perusahaan Tahu Sari Rasa dalam meningkatkan penjualannya, meliputi; 1) Produk, yaitu memberikan produk yang berkualitas dan mampu bersaing dengan produk lainnya. 2) Harga, yaitu menetapkan harga yang umum. 3) Promosi, yaitu menggunakan promosi yang masih tradisional yaitu, penjualan dan personal selling. 4) Distribusi disini meliputi distribusi langsung dan distribusi tidak langsung. Namun masih ada kekurangan yang menjadi faktor penghambat dalam penjualan yaitu segi promosi pada perusahaan Tahu Sari Rasa yang masih tradisional.

Dan kedua, tinjauan etika bisnis Islam terhadap Strategi pemasaran dalam meningkatkan penjualan pada perusahaan Tahu Sari Rasa sudah sesuai dengan nilainilai dalam etika bisnis Islam. Hal tesebut dibuktikan yakni : jujur, adil, tolong menolong dan tidak menyembunyikan cacat produk. Bahwa perusahaan tersebut menyakini bahwa apa yang dijual bukan semata-mata untuk mendapatkan keuntungan sebagai tujuan duniawi saja, melainkan juga untuk mendapatkan keberkahan dan keridhaan dari Allah SWT atas apa yang diusahakan.

\section{DAFTAR PUSTAKA}

Alma, Buchari. Kewirausahaan. Bandung: Alfabeta, 2009.

Al-Qardhawi, Yusuf. Norma dan Etika Ekonomi Islam. Jakarta: Gema Insani Press, 1997.

Amalia, Aisyah. "Perencanaan Strategi Pemasaran Dengan pendekatan Bauran Pemasaran Popsy Tubby", Jurnal Manajemen dan Start-up Bisnis, Vol. 1, No. 3 (Agustus, 2016).

Anoraga, Panji. Manajemen Bisnis. Jakarta: PT. Asdi Mahasatya, 2004.

Arifin, Dimas Hendika Wibowo Zainul. "Analisis Strategi Pemasaran Untuk Meningkatkan Daya Saing UMKM", Jurnal Administrasi Bisnis, Vol. 29, No. 1 (Desember, 2015).

Arminsyurita, "Analisis Strategi Pemasaran Jamur Rimba Jaya Mushrom", Jurnal Ilmiah Ilmu Administrasi, Vol. IV, No. 2 (September, 2014).

Aziz, Abdul. Etika Bisnis Perspektif Islam. Bansung: Alfabeta, 2013.

Boyd, Harper W. Manajemen Pemasaran, Edisi Kedua, Jakarta: Erlangga, 2000.

Bungin, Burhan. Metodologi Penelitian Sosial. Surabaya: Airlangga University Press, 2001.

Hariadi, Doni. "Pengaruh Produk, Harga, Promosi dan Distribusi terhadap Keputusan Pembelian", Jurnal Ilmu dan Riset Manajemen (2012).

https://dalamislam.com/hukumislam/ekonomi/etika-pemasarandalam-islam diakses pada tanggal 17 Desember 2017.

Imaniyati, Neni Sri. Hukum Ekonomi dan Ekonomi Islam. Bandung: Mandar Maju, 2002.

Kertajaya, Hermawan dan Muhammad Syakir Sula. Syari'ah Marketing. Bandung: Mizan, 2006.

Kotler, Philip \& Gary Armstrong. Principles of Marketing (Nith Edition), Prentice Hall. New Jersey: Upper Saddle River, 2001. 
Kotler, Philip dan Armstrong. Dasar-dasar Pemasaran, Edisi Kesembilan. Jakarta: PT. Indeks, 2004.

Kotler, Philip dan Kevin Lane Keller. Manajemen Pemasaran, Edisi ke Tiga Belas Jilid 2. Jakarta: Erlangga, 2009.

Kotler, Philip Kotler. Manajemen Pemasaran, Analisis, Perencanaan dan Mengendalikan, Edisi Kelima, Jilid I. Jakarta: Erlangga, 1986.

Kotler, Philip, et.al. Manajemen Pemasaran Sudut Pandang Asia. Jakarta: PT. Indeks, 2004.

Moleong, Lexy J. Metode Penelitian Kualitatif, Cet. XXIV. Bandung: PT. Remaja Rosdakarya, 2007.

Muhammad, dan Alimin. Etika dan Perlindungan Konsumen. Yogyakarta: BPFE, 2004.

Sugiono. Metode Penelitian Kuantitatif, Kualitatif dan $R$ \& $D$. Bandung: Alfabeta, 2013.

Swashta, Basu. Manajemen Pemasaran Modern. Yogyakarta: Liberty, 1999.

Swastha, Basu. Manajemen Penjualan, Edisi 3. Yoyakarta: BPFE Universitas Gadjah Mada, 1998.

Syafe'i, Rachmat. Fiqh Mu'amalah. Bandung: CV. Pustaka Setia, 2004.

Tjiptono, F. Strategi Pemasaran. Yogyakarta: Penerbit Andi Offset, 1995.

Tjiptono, Fandi. Strategi Bauran Pemasaran. Yogyakarta: YPPM FE, 2001.

Umar, Husein. Strategic Management in Action. Jakarta: PT. Gramedia Pustaka Utama, 2001. 